\title{
Lipid abnormalities in workers exposed to dioxin
}

\author{
J V MARTIN \\ From Oldham and District General Hospital, Oldham OL1 2JH, UK
}

\begin{abstract}
Ten years after an incident in which workers were exposed to tetrachlorodibenzodioxin (TCDD) a controlled biochemical study showed statistically significant increases in the serum cholesterol and triglyceride concentrations of workers both with and without chloracne. Urinary excretion of D-glucaric acid was significantly higher for all workers.
\end{abstract}

Tetrachlorodibenzodioxin (TCDD) is a potent multisystem toxin with high acute toxicity, the LD 50 for several species being of the order of $0.1 \mathrm{mg} / \mathrm{kg}$ bodyweight.' Other toxic effects include chloracne, impaired liver function, carcinogenesis, lipid abnormalities, porphyria, peripheral neuropathy, and psychiatric disturbances. ${ }^{12}$

It has been suggested that some of the toxic effects of TCDD may be linked to its enzyme inducing action..$^{3-5}$ In epidemiological research on subjects exposed to TCDD life style factors such as social class, alcohol intake, dietary and smoking habits, and drug therapy could have a confounding effect $^{\circ}$ because of differences between subjects and controls in the extent of enzyme induction due to agents other than TCDD. In this study, therefore, the subject and control populations were matched for age, social class, alcohol intake, smoking habits, height/weight ratios, and drug therapy.

Subjects with and without chloracne who had been exposed to TCDD were tested as, although the presence of chloracne is a good indicator of exposure to TCDD, evidence from a study of workers exposed to a different chloracnegen ${ }^{7}$ shows that it does not necessarily follow that its absence in an individual exposed to TCDD precludes the possibility of other toxic manifestations.

\section{Subjects}

Three groups of subjects were recruited.

Group $A-$ One hundred and twenty control subjects from an engineering works where there was no exposure to organic chemicals. Most were operatives on shift work but some were management staff.

Received 4 January 1983

Accepted 31 January 1983
Group B-Fifty four subjects, mainly shift workers but including some laboratory and management staff, with varying levels of exposure to TCDD, but who had never had chloracne.

Group C-Forty one subjects, mainly shift workers but including some laboratory and management staff, who had been diagnosed as having chloracne.

\section{Methods}

Subjects were asked to fast for 10 hours (overnight) and a venepuncture sample of blood was obtained at 930 am for the following biochemical tests: alkaline phosphatase, alanine and aspartate aminotransferase, bilirubin, protein corrected calcium, total and HDL cholesterol, triglyceride and gammaglutamyl transferase (GGT). D-glucaric acid/creatinine ratios (DGA) were measured on a sample of urine taken at the same time. All estimates were carried out using standard methodology in two NHS laboratories with some of the analyses being carried out in both laboratories.

\section{Results}

The table shows the means and range of values, plus the laboratory's normal range for those of the tests where there were differences between the subjects and controls. Mean cholesterol and triglyceride are significantly higher in groups $B$ and $C$ than in the controls. The parameters of enzyme induction, GGT and DGA, were raised in both groups of subjects but only in respect of DGA were they significantly higher than the controls. Serum bilirubin and protein corrected calcium concentrations were lower in both groups of subjects, although only for the latter did they differ significantly from the controls. The correlation coefficient $(r)$ for the relationship between GGT and triglyceride in the subjects exposed to TCDD was $+0.44, p<0.001$. 
Biochemistry: mean values

\begin{tabular}{|c|c|c|c|c|c|}
\hline Test (units) & $\begin{array}{l}\text { Laboratory } \\
\text { normal range }\end{array}$ & $\begin{array}{l}\text { Controls mean } \\
\text { (and range) } \\
(n=126)\end{array}$ & $\begin{array}{l}\text { Subjects without } \\
\text { chloracne mean } \\
\text { (and range }) \\
(n=53)\end{array}$ & $\begin{array}{l}\text { Subjects with } \\
\text { chloracne mean } \\
\text { (and range) } \\
(n=39)\end{array}$ & $\begin{array}{l}\text { All subjects mean } \\
(\text { and range }) \\
(n=92)\end{array}$ \\
\hline $\begin{array}{l}\text { Cholesterol } \\
\text { (mmol/1) } \\
\text { Triglyceride } \\
\text { (mmol/l) } \\
\text { HDL cholesterol } \\
\text { (mmoll) } \\
\text { Gammaglutamyl transferase } \\
\text { (U/I at } 37^{\circ} \mathrm{C} \text { ) } \\
\text { D-glucaric acid } \\
\text { (ratio) } \\
\text { Bilirubin } \\
\text { ( } \mu \text { moll) } \\
\text { Protein corrected calcium } \\
\text { (mmol/l) }\end{array}$ & $\begin{array}{l}\text { Up to } 35 \\
\text { Up to } 3.5\end{array}$ & $\begin{array}{l}5 \cdot 6 \\
(2 \cdot 8-8 \cdot 3) \\
1 \cdot 41 \\
(0 \cdot 3-3 \cdot 2) \\
1 \cdot 25 \\
(0 \cdot 8-2 \cdot 02) \\
32 \\
(11-90) \\
1 \cdot 59 \\
(0 \cdot 8-8 \cdot 3) \\
10 \cdot 47 \\
(5-23) \\
2 \cdot 33 \\
(2 \cdot 13-2 \cdot 46)\end{array}$ & $\begin{array}{l}6 \cdot 14^{*} \\
(4 \cdot 5-8 \cdot 6) \\
1 \cdot 90^{*} \\
(0 \cdot 4-4 \cdot 6) \\
1 \cdot 23 \\
(0 \cdot 65-2 \cdot 12) \\
36 \\
(10-120) \\
2 \cdot 09 \\
(0 \cdot 7-7 \cdot 6) \\
10 \cdot 1 \\
(5-22) \\
2 \cdot 307 \\
(2 \cdot 14-2 \cdot 47)\end{array}$ & $\begin{array}{l}6 \cdot 02^{* *} \\
(2 \cdot 9-8 \cdot 1) \\
1 \cdot 97^{* * * *} \\
(0 \cdot 4-4 \cdot 0) \\
1 \cdot 19 \\
(0 \cdot 89-1 \cdot 88) \\
40 \\
(14-91) \\
2 \cdot 09 \\
(0 \cdot 7-7 \cdot 9) \\
9 \cdot 5 \\
(4-23) \\
2 \cdot 282^{* * * *} \\
(2 \cdot 10-2 \cdot 61)\end{array}$ & $\begin{array}{l}6 \cdot 09^{* * *} \\
(2 \cdot 9-8 \cdot 6) \\
1 \cdot 93^{* * *} \\
(0 \cdot 4-4 \cdot 6) \\
1 \cdot 22 \\
(0 \cdot 65-2 \cdot 12) \\
37 \cdot 4 \\
(10-120) \\
2 \cdot 09^{* *} \\
(0 \cdot 7-7 \cdot 9) \\
9 \cdot 84 \\
(4-23) \\
2 \cdot 285^{* * *} \\
(2 \cdot 10-2 \cdot 61)\end{array}$ \\
\hline
\end{tabular}

${ }^{*} \mathrm{p}<0.005 ;{ }^{* *} \mathrm{p}<0.05 ;{ }^{* * *} \mathrm{p}<0.001 ;{ }^{* * *} \mathrm{p}<0.01$. Level of significance of the difference between the means of subjects and controls.

\section{Discussion}

This work confirms previous findings of a relationship between human TCDD exposure and abnormalities of all three lipid fractions estimated. ${ }^{8-13}$ Lipid abnormalities in experimental animals exposed to TCDD are also well recognised. ${ }^{14-16}$

The consensus of opinion is that raised total cholesterol and low HDL cholesterol concentrations probably confer an increased risk of ischaemic vascular disease. ${ }^{17}$ A recent study has also shown a convincing relationship between raised triglycerides and coronary atheroma. ${ }^{18}$ Consistently, two small human studies $^{213}$ and one uncontrolled study (A P Redgrave, personal communication) have suggested a link between exposure to TCDD and ischaemic vascular disease, and there have been two case reports of premature coronary atheroma, diagnosed clinically and by angiography in sprayers of the herbicide 2, 4, 5-T which is contaminated with varying amounts of TCDD. ${ }^{19}$ Intravascular thrombosis has also occurred in rats exposed to TCDD. ${ }^{20}$ The failure to show an increased incidence of ischaemic vascular disease in two studies of workers exposed to $\mathrm{TCDD}^{621}$ may have been due to failure to include an adequate proportion of all affected employees in the first study (A P Redgrave and J V Martin, personal observations) and failure to include subjects without chloracne in the second.

The significant positive correlation between GGT and triglyceride, the significantly lower serum calcium concentrations, and the significantly higher DGA concentrations support the hypothesis that enzyme induction by the TCDD could be the explanation for the abnormal lipid concentrations. The duration of the abnormalities in years rather than months is not an argument against this as has been suggested, ${ }^{6}$ because raised DGA concentrations were found up to three years later in the TCDD exposed Seveso population. ${ }^{22}$ Whatever the mechanism for the lipid abnormalities, they have been found to persist for 10 years in another controlled study of workers exposed to TCDD..$^{23}$

This comparison of TCDD exposed workers with a control group matched for social class and known relevant variables confirms other workers' findings by various experimental approaches of TCDD induced lipid abnormalities and their possible clinical consequences.

\section{References}

' International Agency for Research on Cancer. Monographs on the evaluation of the carcinogenic risk of chemicals to man. Vol 15. Lyon: IARC, 1977.

2 Joint National Institute of Environmental Health Sciences International Agency for Cancer Research Working Group report. Long-term hazards of polychlorinated dibenzodioxins and polychlorinated dibenzofurans. Lyon: IARC, 1978.

${ }^{3}$ Neal RA, Beatty P. Influence of enzyme induction on TCDD toxicity. In: Cattabeni F, Cavallaro A, Galli G, eds. Dioxin toxicological and chemical aspects. New York: SP Medical and Scientific Books, 1978.

4 Tung TT. Pathologie humaine et animale de la dioxine. La Revue de Medicine 1977;14:653-7.

5 Poland A, Glover E. An estimate of the maximum in vivo covalent binding of $2,3,7,8$-tetrachlorodibenzo-p-dioxin to rat liver protein, ribosomal RNA, and DNA. Cancer Res 1979;39:3341-4.

- May G. Tetrachlorodibenzodioxin: a survey of subjects ten years after exposure. Br J Ind Med 1982;39:128-35.

7 Scarisbrick DA, Martin JV. Biochemical changes associated with chloracne in workers exposed to tetrachloroazobenzene and tetrachloroazoxybenzene. J Soc Occup Med 1981;31:158-63.

${ }^{8}$ Dugois P, Colomb L. Remarques sur l'acné chlorique à propos d'une éclosion de cas provoques par la préparation du 24-5-trichlorophénol. Journal de Médecin de Lyon 1957;38:899-903. 
9 Jirasek L, Kalensky J, Kubeck K, Pazderova J, Lukos E. Acne chlorina, porphyria cutanea tarda and other manifestations of general intoxication during the manufacture of herbicides. Ceskoslovenska Dermatologie 1974;49:145-57.

${ }^{10}$ Poland AP, Smith D, Metter G, Possick P. A health survey of workers in a 2, 4-D and 2, 4, 5-T plant with special attention to chloracne, porphyria cutanea tarda and psychlogic parameters. Arch Environ Health 1971;22:316-27.

" Ashe WF, Suskind RR. Progress report-patients from Monsanto Chemical Company, Nitro, West Virginia, 1959. Quoted by Hay, AWM in: The chemical scythe: lessons of 2, 4, 5-T and dioxin. New York and London: Plenum Press, 1982.

${ }_{12}$ Oliver RM. Toxic effects of 2, 3, 7, 8-tetrachlorodibenzo 1, 4-dioxin on laboratory workers. Br J Ind Med 1975;32:49-53.

${ }^{13}$ Walker AE, Martin JV. Lipid profiles in dioxin exposed workers. Lancet 1979; i:446-7.

14 Gasiewicz TA, Neal RA. 2, 3, 7, 8-tetrachlorodibenzo-p-dioxin tissue distribution, excretion and effects on clinical chemical parameters in guinea pigs. Toxicol Appl Pharmacol 1979;51:329-39.

is Zinkl JG, Vos JG, Moore JA, Gupta BN. Haematologic and clinical chemistry effects of 2, 3, 7, 8-tetrachlorodibenzop-dioxin in laboratory animals. Environ Health Perspect 1973;5:111-8.

${ }^{16}$ Cunningham MH, Williams DF. Effect of tetrachlorodibenzo- p-dioxin on growth rate and the synthesis of lipids and proteins in rats. Bull Environ Contam Toxicol 1972;7:45-51.

${ }^{17}$ Lewis B. Dietary prevention of ischaemic heart disease-a policy for the 80s. Br Med J 1980;281:177-80.

${ }^{18}$ Cabin HS, Roberts WC. Relation of serum total cholesterol and triglyceride levels to the amount and extent of coronary arterial narrowing by atherosclerotic plaque in coronary heart disease. Am J Med 1982;73:227-34.

${ }^{19}$ England JF. Herbicides and coronary ectasia. Med J Aust 1980;1:140.

${ }^{20}$ Kociba RJ, Kayes DG, Beyer JE, et al. Results of a two year chronic toxicity and oncogenicity study of $2,3,7$, 8-tetrachlorodibenzo-p-dioxin in rats. Toxicol Appl Pharmacol 1978;46:279-303.

${ }^{21}$ Zack JA, Suskind RR. The mortality experience of workers exposed to tetrachlorodibenzodioxin in a trichlorophenol accident. JOM 1980;22:11-4.

${ }^{22}$ Ideo G, Bellati G, Bellobuono A, Mocarelli P, Marocchi A, Brambilla P. Increased urinary D-glucaric acid excretion by children living in an area polluted by tetrachlorodibenzoparadioxin (TCDD). Clin Chim Acta 1982;120:273-83.

${ }^{23}$ Vejlupkova JP, Nemkova M, Pickova J, Jirasek L. The development and prognosis of chronic intoxication by tetrachlorodibenzo-p-dioxin in men. Arch Environ Health 1981;36:5-11. 